\title{
Pengembangan Media Permainan Simulasi Jujur Tantangan untuk Meningkatkan Penyesuaian Sosial Siswa SMP Laboratorium UM Malang
}

\author{
Mukhlishotin Nabilah*, Adi Atmoko, Elia Flurentin \\ Universitas Negeri Malang, Jl. Semarang No. 5 Malang, Jawa Timur, Indonesia \\ *Penulis korespondensi, Surel: mukhlishotin.nabilah.1601116@students.um.ac.id.
}

Paper received: 2-2-2021; revised: 20-2-2021; accepted: 27-2-2021

\begin{abstract}
The purpose of this research development is to generating an honest challenge simulation game product to increasing students social adjustment. The steps development in this research are adjusted to the research needs, namely (1) data collection (2) planning (3) development of the initial product draft (4) expert testing (5) product revision after expert testing (6) prospective user testing (7) revision the final product. Experts and prospective product users are analyzed using inter-rater agreement models (Gregory, 2011). Test validity index subject matter experts, media and prospective product users showed very high criteria. These products meet very precise criteria, very useful, very easy and very attractive to mean very feasible to use. Based on the test can be concluded that the simulation game of honest challenge to increase the social adjustment of junior high school have met the acceptance criteria.
\end{abstract}

Keywords: media game; simulation game; social adjustment

\begin{abstract}
Abstrak
Tujuan dari penelitian ini adalah untuk menghasilkan produk permainan simulasi jujur tantangan untuk meningkatkan penyesuaian sosial siswa. Langkah pengembangan dalam penelitian ini disesuaikan dengan kebutuhan penelitian yaitu (1) pengumpulan data (2) perencanaan (3) pengembangan draft produk awal (4) uji coba ahli (5) revisi produk setelah uji ahli (6) uji calon pengguna (7) revisi produk akhir. Uji ahli dan uji calon pengguna dianalisis menggunakan interrater agreement model (Gregory, 2011). Indeks validitas uji ahli materi, media dan calon pengguna produk menunjukkan kriteria sangat tinggi. Produk ini memenuhi kriteria sangat tepat, sangat berguna, sangat mudah dan sangat menarik sehingga bermakna sangat layak untuk digunakan. Berdasarkan uji tersebut dapat disimpulkan bahwa media permainan simulasi jujur tantangan untuk meningkatkan penyesuaian sosial siswa SMP telah memenuhi kriteria keberterimaan.
\end{abstract}

Kata kunci: media permainan; permainan simulasi; penyesuaian sosial

\section{Pendahuluan}

Manusia merupakan makhluk sosial yang tidak dapat hidup sendiri-sendiri dan selalu mengadakan interaksi dengan lingkungan untuk memenuhi berbagai kebutuhan dan mencapai hubungan yang harmonis dengan lingkungannya. Salah satu masalah yang dihadapi siswa ketika memasuki masa remaja adalah menyesuaikan dirinya dengan kehidupan baru, yaitu kehidupan dari masa anak-anak menuju masa dewasa awal. Masa transisi inilah yang membawa banyak kesulitan untuk beradaptasi dengan lingkungan yang baru.

Penyesuaian sosial adalah salah satu tugas perkembangan yang tersulit bagi remaja. Menurut definisi yang diberikan oleh Scheneiders dalam bukunya yang berjudul "Personal 
Adjustment and Mental Health" (1984) menjelaskan sebagai berikut: Sosial adjustment signifies the capacity to react affectively and wholesomely to sosial realities, situation and relations do the requirement for social living are fulfilled in an acceptable and satisfactory manner". Makna dari definisi di atas dapat diartikan bahwa penyesuaian sosial merupakan kemampuan untuk bereaksi secara efektif dan sehat terhadap situasi, realitas, relasi sosial sehinga tuntuntan hidup bermasyarakat dipenuhi dengan cara yang dapat diterima dan memuaskan. Penyesuaian sosial pada masa remaja dipengaruhi kemampuan penyesuaian diri setiap individu.

Setiap manusia membutuhkan relasi dan komunikasi dengan manusia yang lain untuk memanusiakan dirinya. Setiap manusia ingin dicintai, ingin diakui dan dihargai, ingin pula mendapatkan tempat di dalam kelompoknya, hanya dengan relasi dan komunikasi dengan manusia lain, manusia dapat menuju pada kedewasaan. Upaya individu mencapai kedewasaan bergantung pada cara penyesuaian sosial yang dilakukannya. Individu diharapkan mampu melakukan sosial dengan bantuan dan dukungan dari manusia lain maupun dirinya sendiri, sehingga manusia dapat berkembang dengan baik dalam berinteraksi dengarn manusia lain. Individu memerlukan penerimaan baik dari orang lain, hal ini akan berdampak jika individu tersebut mampu melaksanakan tuntutan yang ada di lingkungan masyarakat agar individu bisa diterima dengan baik oleh lingkungannya. Hal ini ditegaskan oleh Hurlock (1991), yang menyatakan bahwa: Individu yang diterima dengan baik mempunyai peluang lebih banyak untuk berpartisipasi dalam kegiatan kelompok teman sebaya, dibandingkan dengan individu yang tidak diterima dengan baik, mereka yang diterima dengan baik oleh kelompoknya akan memperoleh kesempatan untuk mempelajari keterampilan sosial, akibatnya secara sosial mereka lebih cakap dibandingkan dengan individu yang pasif.

Pada masa perpindahan dari Sekolah Dasar ke Sekolah Menengah Pertama biasanya individu sangat sulit untuk melakukan penyesuaian sosial, hal ini disebabkan pergaulan untuk penyesuaian sosial siswa lebih sulit dikarenakan lingkungan yang baru serta kelompok sosial yang baru dan biasanya individu tidak dapat menerima kekurangan-kekurangan yang ada dalam diri teman sebayanya. Winkel (2006) menegaskan bahwa perpindahan dari Sekolah Dasar kesatuan pendidikan lanjutan ini merupakan langkah yang cukup berarti dalam kehidupan individu, baik karena tambahan tuntutan belajar bagi siswa lebih berat, maupun karena siswa akan mengalami banyak perubahan dalam diri sendiri selama tahun tahun ini.

Berdasarkan hasil observasi pra penelitian di kelas VII SMP Laboratorium UM Malang diperoleh data awal permasalahan penyesuaian sosial siswa bahwasanya beberapa siswa kelas VII SMP Laboratorium UM memiliki penyesuaian sosial yang rendah. Dibuktikan dengan adanya prilaku siswa yang suka bergerombol dengan teman-teman tertentu, memilih-milih teman untuk kelompok belajar, konflik antar teman, daninteraksi yang kurang terhadap siswa yang berkebutuhan khusus serta siswa yang sering tidak masuk sekolah tanpa keterangan.

Ada banyaknya permasalahan yang terjadi di kehidupan siswa, hal tersebut dapat diminimalisir dengan adanya layanan bimbingan kelompok. Dari bimbingan kelompok dapat dibentuk banyak teknik yang menarik, sehingga dalam bimbingan kelompok tersebut tidak 
merasa membosankan para siswa. Dalam bimbingan kelompok ada banyak teknik yang digunakan, salah satunya yang dinilai efektif yaitu teknik permainan simulasi.

Menurut (Yusuf, 2011) beberapa manfaat belajar sambil bermain adalah menyingkirkan keseriusan yang menghambat, menghilangkan stres dalam lingkungan belajar, mengajak siswa terlibat penuh dalam pembelajaran, meningkatkan proses belajar, membangun kreatifitas diri, mencapai tujuan dengan ketidaksadaran, meraih makna belajar melalui pengalaman dan memfokuskan siswa sebagai subjek belajar.

Dalam upaya meningkatkan penyesuaian sosial peneliti akan menggunakan bimbingan kelompok dengan teknik permainan simulasi. Teknik permainan simulasi lebih menekankan pada keterlibatan dan keaktifan siswa. Menurut Adams (dalam Romlah, 2013:118) "permainan simulasi adalah permainan yang dimaksudkan untuk merefleksikan situasisituasi yang terdapat dalam kehidupan yang sebenarnya". Di dalam permainan simulasi, siswa melakukan kegiatan bermain, diskusi, dan simulasi. Tujuan permainan simulasi untuk memahami suatu konsep dan mengintegrasikannya ke dalam kehidupan sehari-hari.

Proses permainan simulasi dapat membuat siswa untuk berlatih dalam memerankan suatu peran. Menurut Romlah (2013: 121), “dalam permainan simulasi memerlukan proses pembagian peserta pemain, baik pemain, penonton, penulis, dll". Dalam masing-masing peserta mempunyai tugas dan tanggungjawab yang berbeda. Siswa dilatih melalui kegiatan kecil berupa melaksanakan tugasnya sesuai dengan peran yang dipegang. Siswa harus memahami dan mengamati bagaimana siswa melaksanakan tugas selama permainan berlangsung. Apabila siswa mampu melaksanakan tugas sesuai peran dengan baik, maka menujukkan sikap yang tanggungjawab pula.

Berdasarkan uraian latar belakang yang telah tertulis, peneliti mengembangkan media dalam bimbingan kelompok dengan teknik permainan simulasi jujur tantangan. Pada permainan jujur tantangan akan dilakukan pengembangan dalam permainannya. Permainan jujur tantangan akan membantu siswa dalam meningkatkan penyesuaian sosial dirinya. Bentuk media yang praktis dan mudah untuk dibawa dan digunakan di mana saja. Jenis media yang memungkinkan dilakukan pada bermacam-macam kondisi. Permainan jujur tantangan ini adalah permainan yang populer di kalangan remaja dan dapat membuat suasana menjadi menyenangkan. Penelitian ini menggunakan subjek siswa dalam jenjang SMP dikarenakan untuk menumbuhkan penyesuaian sosial yang efektif sejak usia remaja awal sebagai bekal untuk diterapkan di jenjang berikutnya

\section{Metode}

Penelitian ini merupakan jenis penelitian dan pengembangan atau Research and Development (R\&D). Adapun langkah-langkah dalam penelitian pengembangan menurut Borg \& Gall (1983) terdiri dari sepuluh langkah. Akan tetapi peneliti menggunakan 7 langkah yang disesuaikan dengan kebutuhan penelitian 1) pengumpulan data, 2) perencanaan, 3) pengembangan draft produk awal, 4) uji coba ahli, 5) revisi produk setelah uji ahli, 6) uji lapangan atau uji calon pengguna, 7) revisi produk akhir.

Pada penelitian dan pengembangan ini uji coba dilakukan melalui dua tahapan yaitu uji ahli dan uji calon pengguna. Tahap pertama yaitu uji ahli materi dan uji ahli media. Uji ahli materi melibatkan dua Dosen jurusan Bimbingan dan Konseling, uji ahli media melibatkan satu Dosen jurusan Bimbingan dan Konseling dan satu dosen jurusan Teknologi Pendidikan. 
Tahap kedua yaitu uji calon pengguna. Uji coba calon pengguna melibatkan dua konselor di SMP Laboratorium UM Malang.

Instrumen yang digunakan dalam penelitian pengembangan ini adalah instrumen uji ahli dan uji calon pengguna. Instrumen uji ahli dan uji calon pengguna dibuat untuk memberikan penilaian terhadap media dan buku panduan yang dikembangkan. Instrumen uji ahli dan uji calon pengguna memiliki format penilaian berupa skala penilaian terkait dengan aspek ketepatan, kebergunaan, kemudahan, dan kemenarikan serta lembar saran dan masukan secara keseluruhan mengenai buku manual yang dikembangkan.

Analisis data kuantitatif hasil uji ahli materi, media, dan calon pengguna menggunakan rumus inter-rater agreement model (Gregori, 2011) kemudian dikategorikan berdasarkan indeks hasil uji validasi ahli. Untuk analisis data kualitatif diperoleh dari penilaian ahli dan calon pengguna berupa kritik, saran dan komentar perbaikan. Instrumen penelitian yang digunakan dalam penelitian ini berupa angket dan skala penilaian (rating scale) 1-4 dimana angka 1 menunjukkan produk tidak layak dan angka 4 menunjukkan produk sangat layak.

Tabel 1. Kategori Indeks Validitas Uji Ahli

\begin{tabular}{cc}
\hline Indeks Uji Ahli & Kategori Validitas \\
\hline $0,76-1,00$ & Sangat Tinggi \\
$0,51-0,75$ & Tinggi \\
$0,26-0,50$ & Sedang \\
$0,00-0,25$ & Rendah \\
\hline
\end{tabular}

\section{Hasil dan Pembahasan}

\subsection{Hasil}

Penelitian dan pengembangan ini menghasilkan sebuah produk permainan simulasi jujur tantangan yang dilengkapi dengan buku panduan yang menarik dan mudah dipahami. Buku panduan yang dihasilkan berisi tentang prosedur pelaksanaan permainan simulasi untuk meningkatkan penyesuaian sosial siswa. Produk yang dihasilkan ditujukan kepada konselor sebagai media dalam memberikan layanan kepada siswa. Media permainan simulasi jujur tantangan terdiri dari beberapa komponen, yaitu kartu jujur, kartu tantangan, dan koin. Buku panduan yang dihasilkan berukuran A5 dengan desain yang menarik sesuai dengan kriteria anak SMP. Buku panduan terdiri dari cover depan, kata pengantar, daftar isi, bagian satu pendahuluan, bagian dua uraian teoritik, bagian tiga prosedur pelaksanaan, bagian empat evaluasi, daftar rujukan dan lampiran.

Uji validitas produk diperoleh dari penilaian uji ahli materi, penilaian uji ahli media, dan uji calon pengguna produk. Data yang didapatkan dari penilaian ahli dan calon pengguna adalah data kuantitatif dan data kualitatif. 
Jurnal Pembelajaran, Bimbingan, dan Pengelolaan Pendidikan, 1(2), 2021, 148-155

Tabel 2. Hasil Penilaian oleh Ahli Materi, Ahli Media, dan Calon Pengguna Produk

\begin{tabular}{|c|c|c|}
\hline Penilaian Ahli Materi & Penilaian Ahli Media & $\begin{array}{l}\text { Penilaian Calon } \\
\text { Pengguna Produk }\end{array}$ \\
\hline $\begin{array}{l}\text { Hasil analisis dengan } \\
\text { menggunakan rumus inter- } \\
\text { rater agreement model } \\
\text { menunjukkan bahwa } \\
\text { media permainan simulasi } \\
\text { jujur tantangan memiliki } \\
\text { indeks uji ahli materi } \\
\text { sebesar } 1 \text { yang berarti } \\
\text { memiliki validitas yang } \\
\text { sangat tinggi. Kedua ahli } \\
\text { memberikan penilaian } \\
\text { dengan relevansi tinggi } \\
\text { terhadap } 29 \text { butir } \\
\text { pernyataan. }\end{array}$ & $\begin{array}{l}\text { Hasil analisis dengan } \\
\text { menggunakan rumus inter- } \\
\text { rater agreement model } \\
\text { menunjukkan bahwa media } \\
\text { permainan simulasi jujur } \\
\text { tantangan memiliki indeks uji } \\
\text { ahli media sebesar 0,5 yang } \\
\text { berarti memiliki validitas } \\
\text { yang sedang. Kedua ahli } \\
\text { memberikan penilaian } \\
\text { dengan relevansi sangat } \\
\text { tinggi terhadap } 18 \text { butir } \\
\text { pernyataan dan } 3 \text { butir } \\
\text { pernyataan yang } \\
\text { mendapatkan relevansi tinggi } \\
\text { dari ahli } 1 \text { dan relevansi } \\
\text { rendah dari ahli } 2\end{array}$ & $\begin{array}{l}\text { Hasil analisis dengan } \\
\text { menggunakan rumus inter- } \\
\text { rater agreement model } \\
\text { menunjukkan bahwa } \\
\text { media permainan simulasi } \\
\text { jujur tantangan memiliki } \\
\text { indeks uji ahli materi } \\
\text { sebesar } 1 \text { yang berarti } \\
\text { memiliki validitas yang } \\
\text { sangat tinggi. Kedua ahli } \\
\text { memberikan penilaian } \\
\text { dengan relevansi tinggi } \\
\text { terhadap } 50 \text { butir } \\
\text { pernyataan }\end{array}$ \\
\hline
\end{tabular}

Ahli materi bimbingan dan konseling, ahli media, dan calon pengguna produk memberikan penilaian yang baik terhadap produk penelitian dan pengembangan ini sesuai dengan aspek keberterimaan yaitu, ketepatan, kegunaan, kemudahan, dan kemenarikan. Data kuantitatif dari kedua ahli materi dan calon pangguna produk pada aspek ketepatan, kegunaan, kemudahan dan kemenarikan menunjukkan indeks validitas 1,00 yang termasuk dalam kategori sangat tinggi. Namun data kuantitatif dari ahli materi pada aspek ketepatan menunjukkan indeks validitas 0,5 yang termasuk dalam kategori sedang sedangkan pada aspek kegunaan, kemudahan dan kemenarikan menunjukkan indeks validitas 1,00 yang termasuk dalam kategori sangat tinggi. Kesimpulan dari data kuantitatif yang didapat penulis tersebut adalah produk media permainan simulasi jujur tantangan untuk meningkatkan penyesuaian sosial siswa SMP sangat berterima sebagai media untuk konselor memberikan layanan bimbingan kelompok terhadap siswa SMP khususnya siswa jenjang kelas VII. Hal ini karena produk telah teruji secara teoritis maupun praktis.

Penulis melakukan revisi sesuai saran dan masukan oleh ahli materi bimbingan dan konseling, ahli media, dan calon pengguna produk yang digunakan sebagai data kualitatif. Saran dan masukan tersebut yaitu perlu konsistensi antara penetapan tujuan pengumpulan data dengan langkah-langkah dalam pelaksanaan permainan simulasi, menambahkan rubrik (pedoman instrumen), menambahkan bagan atau alur pelaksanaan dan memperhatikan kembali kesalahan dalam penulisan. Selain itu ahli media menyebutkan bahwa desain produk sebaiknya mencerminkan variabel yang dikembangkan. Hasil perbaikan tersebut diperoleh produk akhir berupa media permainan jujur tantangan yang dilengkapi buku panduan. Produk ini diharapkan dapat membantu konselor dalam memberikan layanan bimbingan kelompok dengan teknik permainan simulasi jujur tantangan untuk meningkatkan penyesuaian sosial siswa SMP Laborarotium UM. Penilaian uji coba produk dapat dilihat bahwa produk yang dikembangkan memenuhi aspek keberterimaan yaitu kegunaan, ketepatan, kegunaan, kemudahan, dan kemenarikan. Sehingga produk yang dikembangkan 
berupa media permainan simulasi jujur tantangan untuk meningkatkan penyesuaian sosial siswa dapat dikatakan layak dan dapat digunakan oleh konselor.

\subsection{Pembahasan}

Penelitian dan pengembangan ini menghasilkan produk berupa buku panduan dan media permainan simulasi jujur tantangan. Produk ini dikembangkan sesuai dengan prosedur penelitian dan pengembangan Borg \& Gall (1983) yang telah disesuaikan dengan kebutuhan yaitu (1) pengumpulan data (2) perencanaan (3) pengembangan draft produk awal (4) uji coba ahli (5) revisi produk setelah uji ahli (6) uji calon pengguna (7) revisi produk akhir. Sebelum produk dihasilkan, peneliti terlebih dahulu melakukan pengamatan kepada siswa selama kegiatan PLP berlangsung. Selain itu peneliti juga melakukan wawancara dengan konselor sekolah dan need assesment kepada siswa pada tanggal 3 September 2020. Konselor mengatakan bahwa masih terdapat siswa yang memiliki penyesuaian sosial rendah. Sikap yang menunjukkan penyesuaian sosial yang rendah antara lain yakni terdapat siswa masih melanggar peraturan sekolah, masih takut mengemukakan pendapat di hadapan orang lain, kurangnya kerjasama dalam kegiatan berkelompok, merasa takut jika tidak diterima di kelompoknya dan sebagainya. Oleh karena itu diperlukan metode untuk meningkatkan penyesuaian sosial siswa di sekolah menggunakan permainan simulasi jujur tantangan.

Teknik permainan simulasi dipilih berdasarkan hakikat permainan simulasi yang mengajarkan siswa agar dapat mengekspresikan dirinya sesuai peristiwa yang terdapat dalam kartu jujur maupun kartu tantangan. Selain itu metode permainan simulasi dipilih karena melalui permainan simulasi siswa bisa melakukan diskusi, bermain dan simulasi Melalui permainan simulasi siswa tidak merasa bahwa sebenarnya mereka juga sedang belajar. Hal ini sesuai dengan pendapat Amri (2017) yang megemukakan bahwa melalui metode pembelajaran bermain peran, anak dilatih untuk mengungkapkan ide, harapan, dan keinginan mereka sesuai imajinasi dengan batasan cerita atau peran yang diberikan. Metode bermain peran juga memberikan suasana baru bagi anak didik dalam proses pembelajaran yang dilakukan dalam suasana bermain tanpa terbebani oleh tugas perkembangannya.

Produk permainan simulasi jujur tantangan ini sangat layak digunakan sebagai bahan atau media belajar untuk siswa. Sesuai dengan pendapat Hamalik (dalam Nurseto, 2011) yang mengatakan bahwa pemanfaatan media dalam pembelajaran dapat membangkitkan keinginan dan minat baru, meningkatkan motivasi dan rangsangan kegiatan belajar, dan bahkan berpengaruh secara psikologis kepada siswa. Produk permainan ini juga dibuat semenarik mungkin, dilengkapi dengan desain film kartun "Toy story" yang disukai semua kalangan terlebih anak-anak.

Ahli materi bimbingan dan konseling, ahli media, dan calon pengguna produk memberikan penilaian yang baik terhadap produk penelitian dan pengembangan ini sesuai dengan aspek keberterimaan yaitu, ketepatan, kegunaan, kemudahan, dan kemenarikan. Produk pengembangan permainan simulasi jujur tantangan ini sangat layak dan sangat tepat untuk meningkatkan penyesuaian sosial siswa SMP. Hal ini karena produk telah teruji secara teoritis maupun praktis.

Terdapat beberapa warna dalam produk permainan simulasi jujur tantangan yaitu, warna biru yang melambangkan segar dan bersih, warna merah yang melambangkan berani dan 
semangat, warna hijau yang melambangkan rasa damai dan bangga, warna merah muda yang melambangkan jenaka dan menggemaskan, warna coklat yang melambangkan solid dan dapat diandalkan, warna kuning yang melambangkan ketulusan. Menurut psikologi warna setiap warna memiliki atri tersendiri, tujuan peneliti menggunakan warna-warna tersebut untuk menarik perhatian siswa.

Peneliti melakukan revisi sesuai saran dan masukan oleh ahli materi bimbingan dan konseling, ahli media, dan calon pengguna produk. Hasil perbaikan tersebut diperoleh produk akhir berupa buku panduan yang dilengkapi media permainan jujur tantangan. Produk ini diharapkan dapat membantu konselor dalam memberikan layanan bimbingan kelompok dengan teknik permainan simulasi jujur tantangan untuk meningkatkan penyesuaian sosial siswa SMP Laborarotium UM.

Berdasarkan paparan paragraf di atas dapat diketahui bahwa buku panduan dan media permainan simulasi jujur tantangan sangat layak digunakan untuk memberikan layanan bimbingan kelompok untuk meningkatkan penyesuaian sosial siswa SMP. Dilengkapi dengan media permainan simulasi jujur tantangan berupa kartu jujur, kartu tantangan, koin aklirik yang dapat menarik minat siswa untuk mengikuti layanan sehingga dapat disimpulkan bahwa produk permainan simulasi jujur tantangan sangat layak digunakan. Dengan demikian konselor dapat menggunakan produk permainan simulasi jujur tantangan untuk memberikan layanan bimbingan kelompok untuk meningkatkan penyesuaian sosial siswa SMP. Penelitian ini didukung oleh penelitian yang dilakukan oleh Muslihati, dkk. (2016) yang menujukkan bahwa permainan simulasi dapat meningkatkan keterbukaan diri siswa SMP. Penelitian lain dilakukan oleh Ramli (2016) mengenai pengembangan media permainan simulasi ular tangga untuk meningkatkan tanggungjawab belajar siswa. Berdasarkan hasil tersebut permainan simulasi dapat meningkatkan beberapa aspek dalam diri siswa sehingga permainan simulasi jujur tantangan juga dapat digunakan untuk meningkatkan penyesuaian sosial siswa SMP.

\section{Simpulan}

Dari hasil analisis data dapat dikatakan bahwa produk dalam penelitian pengembangan ini telah layak digunakan dengan memenuhi kriteria akseptabilitas yang terdiri dari aspek ketepatan, kegunaan, kemudahan, dan kemenarikan. Hasil uji ahli dan uji calon pengguna produk menunjukkan bahwa produk sangat tepat digunakan dengan kategori nilai yang tinggi sehingga produk dapat digunakan oleh konselor dalam memberikan layanan. Adapun kelebihan produk ini adalah dapat membuat siswa lebih antusias dan bersemangat dalam mengikuti layanan, selain itu buku panduan yang berukuran A5 mudah dibawa dan digunakan oleh konselor. Namun produk ini juga memiliki kelemahan yakni penggunaan permainan jujur tantangan memerlukan waktu untu menjelaskan kepada siswa, permainan jujur tantangan tidak dapat mengembangkan semua materi pelajaran, dan kurangnya pemahaman aturan permainan oleh siswa yang dapat menimbulkan kericuhan.

\section{Daftar Rujukan}

Amri, N. A. (2017). Pengaruh Metode Bermain Peran Terhadap Kemampuan Komunikasi (Bahasa Ekspresif) Anak Taman Kanak-Kanak Raudhatul Athfal Alauddin Makassar. Pembelajar: Jurnal Ilmu Pendidikan, Keguruan, dan Pembelajaran, 1(2), 105-110.

Borg, W. R. \& Gall, M. D. (1983). Educational Research An Introduction. New York: Longman Inc.

Gregory, R. J. (2011). Psychologycal Testing. History, Principles, and Aplications. Boston: Allyn \& Bacon.

Hurlock, E. B. (1991). Perkembangan Anak. Jakarta: Erlangga 
Jurnal Pembelajaran, Bimbingan, dan Pengelolaan Pendidikan, 1(2), 2021, 148-155

Jannah, R., Zen, E. F., \& Muslihati, M. (2016). Pengembangan permainan simulasi keterbukaan diri untuk siswa SMP. Jurnal Kajian Bimbingan dan Konseling, 1(2), 74-78.

Nurseto, T. (2011). Membuat media pembelajaran yang menarik. Jurnal Ekonomi dan pendidikan, 8(1).

Putri, S. A., \& Ramli, M. (2016). Pengembangan media permainan simulasi ular tangga untuk meningkatkan tanggung jawab belajar siswa SMP. Jurnal Kajian Bimbingan dan Konseling, 1(1), 40-46.

Romlah, T. (2013). Teori dan Praktek Bimbingan Kelompok. Malang: Penerbit Universitas Negeri Malang

Scheneider, A. A. (1984). Personal Adjustment and Mental Health. New Delhi: Tata Mc.Graw-Hill Publishing Company Limited

Winkel, W. S., \& Hastuti, M. S. (2006). Bimbingan dan konseling di institusi pendidikan. Media Abadi.

Yusuf. (2011). Sirkuit Pintar Melejitkan Kemampuan. Jakarta: Visi Media 